$M$ Jarvis, $M$ Raw, and $S \mathrm{R}$ Sutton gave useful advice during the analysis and write-up. Financial support was provided by the Department of Health and Social Security and the Medical Research Council.

\section{References}

1 Baker, C D, fournal of the Royal College of General Practitioners, 1976, 26, 404.

${ }^{2}$ D'Souza, M F, Swan, A V, and Shannon, D J, Lancet, 1976, 1, 1228

3 Office of Population Censuses and Surveys, The General Household Survey 1972. London, HMSO, 1975.

4 Ashford, J R, British Fournal of Preventive and Social Medicine, 1973, 27, 8.

5 Klapper, J T, The Effects of Mass Communication, Illinois, Free Press, 1960.

${ }^{6}$ Burns, B H, British Fournal of Preventive and Social Medicine, 1969, 23, 23.

7 Williams, H O, Practitioner, 1969, 202, 672.

${ }^{8}$ Pincherle, G, and Wright, H B, Practitioner, 1970, 205, 209.
- Rose, G, in Proceedings of 3rd World Conference on Smoking and Health, ed J Steinfeld et al, vol 2, p 515. US Department of Health, Education and Welfare, 1976.

10 Rose, G, and Udechuku, J C, British fournal of Preventive and Social Medicine, 1971, 25, 160 .

11 Mausner, J S, Mausner, B, and Rial, W J, American fournal of Public Health, 1968, 58, 46.

12 Porter, A M W, and McCullough, D M, Practitioner, 1972, 209, 686

13 Handel, S, Postgraduate Medical fournal, 1973, 49, 679.

14 Burnum, J F, Annals of Internal Medicine, 1974, 81, 387.

15 Leventhal, H, Watts, J C, and Pagano, F, Fournal of Personality and Social Psychology, 1967, 6, 313.

${ }^{16}$ Ley, P, Jain, V K, and Skilbeck, C E, Psychological Medicine, 1976, 6, 599.

${ }^{17}$ Feyerabend, C, and Russell, M A H, fournal of Pharmacy and Pharmacology, 1979, 31, 73.

18 Russell, M A H, British Medical fournal, 1971, 2, 393.

19 McKennell, A C, and Thomas, R K, Adults' and Adolescents' Smoking Habits and Attitudes. London, HMSO, 1967.

(Accepted 11 fune 1979)

\title{
Inhibition of reticuloendothelial function by gold and its relation to postinjection reactions
}

\author{
B D WILLIAMS, C M LOCKWOOD, B A PUSSELL
}

British Medical fournal, 1979, 2, 235-237

\section{Summary and conclusions}

A patient with rheumatoid arthritis developed severe exacerbation of symptoms 18 hours after an injection of gold thiomalate (sodium aurothiomalate). Immune complexes were present in his serum and synovial fluid; in the synovial fluid they were associated with intense complement activation. The effect of gold salts on splenic reticuloendothelial function was determined by measuring the clearance of heat-damaged erythrocytes from the circulation. Gold thiomalate $(50 \mathrm{mg})$ substantially delayed clearance in the patient but had no effect in four other patients with rheumatoid arthritis who had not had a postinjection reaction. Severely impaired clearance also occurred in three out of four healthy people given $100 \mathrm{mg}$ gold but they remained asymptomatic.

The postinjection reaction may be an immunecomplex disease that is triggered in certain patients because gold transiently inhibits reticuloendothelial function.

\section{Introduction}

Gold is well established for treating rheumatoid arthritis, and in several clinical trials ${ }^{1-3}$ treatment not only reduced symptoms but slowed or even halted the disease. The major limiting factor

Royal Postgraduate Medical School, Hammersmith Hospital, London W12 0HS

B D WILLIAMS, MSC, MRCP, senior lecturer in immunology and consultant physician, and honorary consultant, department of rheumatology C M LOCKWOOD, MRCP, research fellow and honorary senior registrar B A PUSSELL, FRACP, research fellow and honorary senior registrar of gold is the incidence of toxic effects: mucocutaneous manifestations are the commonest, but other side effects such as marrow depression and the nephrotic syndrome are well documented. A side effect that has not been well defined is the transient increase in rheumatic symptoms after the injection of gold-the so-called non-vasomotor postinjection reaction. These reactions are usually mild but occasionally may be so severe that treatment is stopped prematurely. We have investigated a patient who had a severe postinjection reaction and present here evidence suggesting that the side effect is initiated by a pronounced inhibitory effect of gold thiomalate (sodium aurothiomalate) on the reticuloendothelial system.

\section{Case report}

A 48-year-old man with seropositive nodular rheumatoid arthritis resistant to non-steroidal anti-inflammatory drugs began treatment with gold. He was given a test dose of gold thiomalate (Myocrisin) $10 \mathrm{mg}$ intramuscularly and a week later received $50 \mathrm{mg}$. Next day he felt generally unwell: the arthralgia and joint stiffness were much more severe, and effusions were noted in knees and ankles. He was confined to bed for $\mathbf{2 4}$ hours and did not fully recover for three days. During the illness his general practitioner prescribed chlorpheniramine (Piriton) $4 \mathrm{mg}$ thrice daily. Clinical recovery coincided with taking this drug.

\section{Methods}

Serum and plasma samples-Blood samples were allowed to clot at room temperature, separated, and stored in small aliquots in liquid nitrogen. Synovial fluid was stored similarly. Plasma was removed from blood collected into EDTA (final concentration $0.01 \mathrm{~mol} / \mathrm{l}$ ) and stored in small aliquots in liquid nitrogen. Synovial fluid was also collected into EDTA before storage.

Complement, $C$-reactive protein, and albumin concentrations- $\mathrm{C} 1 \mathrm{q}$, C3, C4, C-reactive protein (CRP), and albumin were measured by radial immunodiffusion with monospecific antisera. Functional total haemolytic complement $\left(\mathrm{CH}_{50}\right)$ and alternative pathway activity were 
determined in a haemolytic plate assay. ${ }^{4}$ Results were expressed by reference to a pool of normal serum. Plasma and synovial fluid C3d concentrations were measured by a two-stage procedure, $\mathrm{C} 3$ and $\mathrm{C} 3 \mathrm{~b}$ and $\mathrm{C} 3 \mathrm{c}$ being precipitated by polyethylene glycol and the C3d concentration in the supernatant determined by radial immunodiffusion. $^{5}$

C1q-binding and conglutinin-binding assays-The C1q-binding $(\mathrm{ClqB})$ assay and conglutinin-binding $(\mathrm{KgB})$ assay for detecting immune complexes were performed as described. ${ }^{6}$ All serum samples were assayed at the same time.

Clearance studies with heat-damaged erythrocytes were conducted by a modified version of the method of Bowring et al. ${ }^{7}$ Blood $(10 \mathrm{ml})$ was collected into heparin-and the samples centrifuged at $1500 \mathrm{~g}$ for five minutes. The packed red blood cells were then heat-damaged at $49.5^{\circ} \mathrm{C}$ for exactly 20 minutes and, after washing, labelled with $25-50 \mu \mathrm{Ci}{ }^{9} 9 \mathrm{mT}$. A freshly prepared $1 \%$ solution of stannous chloride was then added and the mixture allowed to stand for a further five minutes. The cells were then washed twice in $\mathrm{NaCl} 9 \mathrm{~g} / \mathrm{l}$, resuspended with an equal volume of saline, and reinjected. Blood samples were taken at $3,8,13,18$, and 23 minutes and the radioactivity per unit volume of whole blood subsequently measured. Results were expressed as a percentage of the three-minute counts and plotted on semi-log paper and the time taken to clear half of the cells from the circulation $\left(t \frac{1}{2}\right)$ calculated.

\section{Results}

The patient was rechallenged in hospital with a second dose of gold thiomalate (Myocrisin) $50 \mathrm{mg}$ intramuscularly. Eighteen hours later he complained of severe joint pain and muscle tenderness and a large effusion was noted in his left knee. Over $95 \%$ of the cells in this fluid (total cell count $0.3 \times 10^{6} / 1(30000 / \mathrm{dl})$ ) were polymorphonuclear leukocytes. The acute exacerbation of symptoms was reflected by a pronounced reduction in grip strength and an increase in walking time (fig 1). Subsequent injections of gold given when he was taking chlorpheniramine (Piriton) $4 \mathrm{mg}$ thrice daily and a placebo (ascorbic acid $50 \mathrm{mg}$ thrice daily) did not produce any clinical deterioration, though a small reduction in grip strength occurred after the third injection.
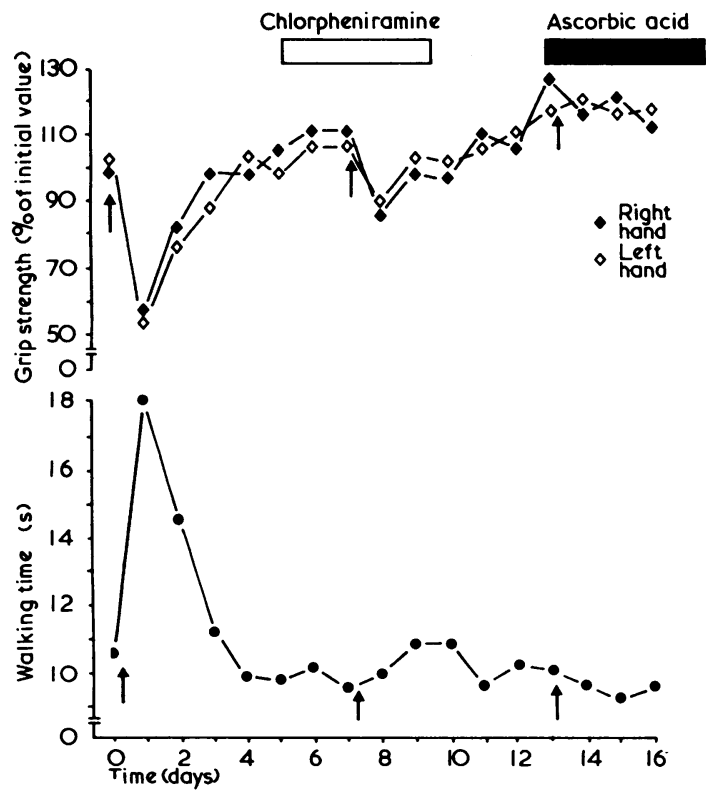

FIG 1 -Changes in grip strength and walking time after injections of gold (arrowed). Injection repeated when patient taking chlorpheniramine and placebo (ascorbic acid).

The most striking finding was the effect of gold thiomalate on the clearance of heat-damaged erythrocytes. The studies were performed six months after beginning treatment, by which time the patient was symptom-free, the erythrocyte sedimentation rate and CRP concentration had fallen to normal, and immune complexes were no longer detectable in the serum. The first clearance study was per- formed two weeks after injecting $50 \mathrm{mg}$ gold, and the second five hours after injecting a similar dose. Even though he had received a total of $610 \mathrm{mg}$ gold thiomalate his initial clearance time was normal $\left(\mathrm{t} \frac{1}{2} 10 \mathrm{~min}\right.$ ); the result of the second clearance study, however, was grossly abnormal ( $t \frac{1}{2}=120 \mathrm{~min}$; fig 2 ).

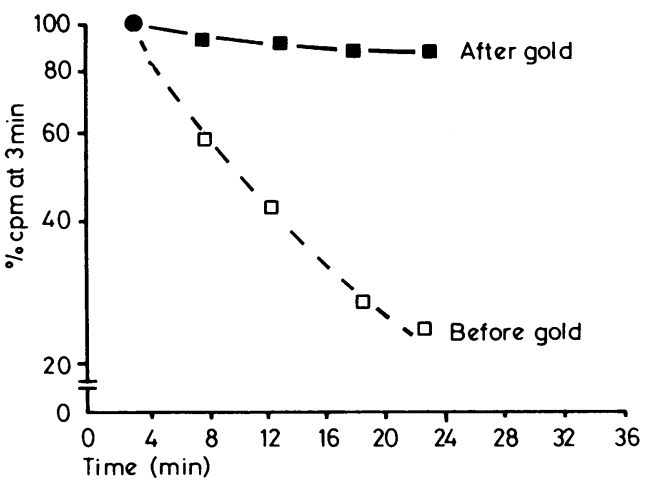

FIG 2-Clearance of heat-damaged red cells before and after injection of gold.

Fig 3 shows the changes in the concentration of immune complexes after injecting gold. Immune complexes, detected with the $\mathrm{ClqB}$ and $\mathrm{KgB}$ assays, were present in the serum before the injection, and their concentration increased after each injection. When the patient was taking antihistamines there was a striking and significant increase in the concentration of $\mathrm{ClqB}$ material $(\mathrm{P}=0.01$; Wilcoxon's rank sum test) but no change in the concentration of $\mathrm{KgB}$ material or albumin. The highest concentrations of immune complexes were found in the synovial fluid and were associated with low complement values and intense complement activation (table I).

The effect of gold (Myocrisin) on the clearance of heat-damaged erythrocytes was also studied in four healthy people and four patients with rheumatoid arthritis who had not had any postinjection reactions. In the healthy subjects the studies were carried out two weeks after a test dose (10 mg intramuscularly) and five hours after injecting $100 \mathrm{mg}$ intramuscularly. Patients with rheumatoid arthritis were tested before they received the drug and five hours after an injection

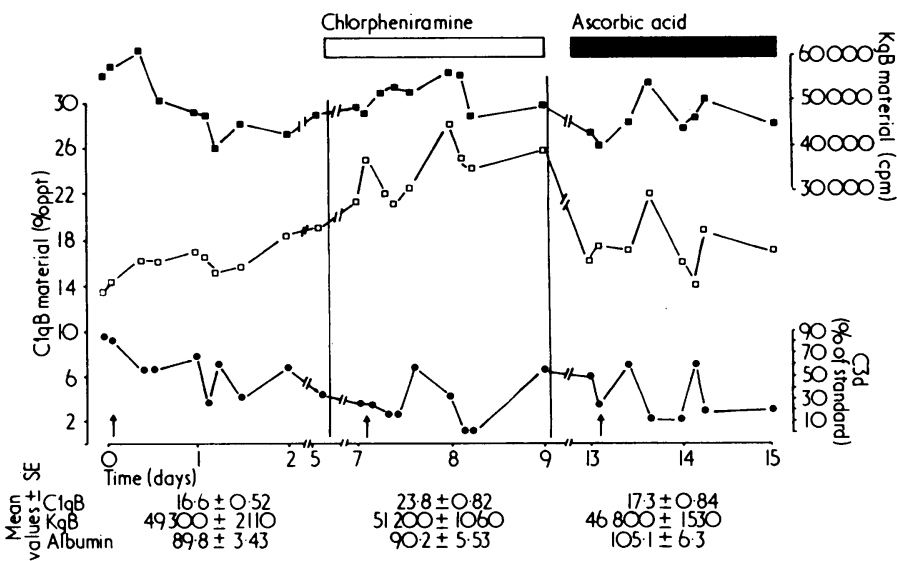

FIG 3-Sequential changes in circulating immune complexes and C3d after injections of gold (arrowed).

TABLE I-Concentrations of complement in serum and synovial fluid before and 20 hours after injection of $50 \mathrm{mg}$ gold thiomalate. (Results expressed by reference to pool of normal sera; see under Methods)

\begin{tabular}{|c|c|c|c|c|c|c|c|c|}
\hline & $\mathrm{CH}_{50}$ & $\mathrm{Clq}$ & $\mathrm{C} 4$ & $\mathrm{C} 3$ & AP & $\underset{\text { min }}{\text { Albu- }}$ & C3d & 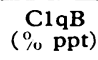 \\
\hline $\begin{array}{l}\text { Before } \quad \ldots \\
\text { After } \\
\text { Synovial fluid }\end{array}$ & $\begin{array}{ll}\ldots & 56 \\
\ldots & 75 \\
\ldots & 25\end{array}$ & $\begin{array}{r}80 \\
100 \\
50\end{array}$ & $\begin{array}{l}40 \\
40 \\
14\end{array}$ & $\begin{array}{r}88 \\
130 \\
21\end{array}$ & $\begin{array}{r}100 \\
100 \\
45\end{array}$ & $\begin{array}{r}80 \\
104 \\
58\end{array}$ & $\begin{array}{r}86 \\
25 \\
130\end{array}$ & $\begin{array}{l}13 \cdot 8 \\
15 \cdot 8 \\
24 \cdot 2\end{array}$ \\
\hline Normal value & . . 50-125 & $60-125$ & $50-120$ & $60-160$ & $60-140$ & $60-155$ & 25 & $4 \cdot 0$ \\
\hline
\end{tabular}

$\mathbf{A P}=$ alternative pathway 
of $50 \mathrm{mg}$ intramuscularly. Table II gives the results. Gold delayed the red-cell clearance in three of the healthy subjects, in two of whom the $t .2$ was substantially increased. Gold had no effect on red-cell clearance in the four patients with rheumatoid arthritis, even though two had prolonged clearance times before starting treatment. One of the healthy subjects was also given $100 \mathrm{mg}$ gold thioglucose (Aureotan) and the red-cell clearance again determined five hours later. Gold thioglucose was much less effective than gold thiomalate in delaying the clearance of damaged red cells.

TABLE II-Effects of gold thiomalate and gold thioglucose on clearance of autologous heat-damaged erythrocytes in normal subjects and patients with rheumatoid arthritis

\begin{tabular}{|c|c|c|c|c|c|c|c|c|}
\hline & & & & & & \multirow{2}{*}{$\begin{array}{c}\text { Before } \\
\text { gold } \\
(\mathrm{min})\end{array}$} & \multicolumn{2}{|c|}{ After gold (min) } \\
\hline & & & & & & & Thiomalate & Thioglucose \\
\hline $\begin{array}{r}\text { Health } \\
1 \\
2 \\
3 \\
4\end{array}$ & $\begin{array}{c}\text { bjec } \\
\ldots \\
\ldots \\
\ldots\end{array}$ & $\begin{array}{l}\cdots \\
\cdots \\
\cdots\end{array}$ & $\begin{array}{l}\cdots \\
\cdots \\
\cdots\end{array}$ & $\begin{array}{l}\cdots \\
\cdots \\
\cdots\end{array}$ & $\begin{array}{l}\cdots \\
\cdots \\
\cdots\end{array}$ & $\begin{array}{r}6 \\
10 \\
9 \\
5\end{array}$ & $\begin{array}{r}>120 \\
28 \\
>120 \\
5\end{array}$ & 23 \\
\hline $\begin{array}{c}\text { Patie } \\
1 \\
2 \\
3 \\
4\end{array}$ & $\begin{array}{c}\text { with } \\
\ldots \\
\ldots \\
\ldots\end{array}$ & $\begin{array}{l}\text { heur } \\
\ldots \\
\ldots \\
\ldots\end{array}$ & $\begin{array}{c}\text { oid } \\
\ldots \\
\ldots \\
\ldots \\
\ldots\end{array}$ & $\begin{array}{c}\text { ariti } \\
\ldots \\
\ldots \\
\ldots \\
\ldots\end{array}$ & $\begin{array}{l}\cdots \\
\cdots \\
\cdots\end{array}$ & $\begin{array}{r}40 \\
70 \\
12 \\
7\end{array}$ & $\begin{array}{r}40 \\
70 \\
12 \\
7\end{array}$ & \\
\hline
\end{tabular}

\section{Discussion}

Patients with rheumatoid arthritis often report a transient worsening of symptoms after an injection of gold salts. Most reviews on the toxic effects of gold, however, either do not mention this side effect or suggest that the postinjection reaction is uncommon or not important. A report of a recent study on 100 patients with rheumatoid arthritis who were admitted to hospital for chrysotherapy challenged this view and drew attention to the relatively high frequency and severity of these reactions and the beneficial effects of substituting gold thioglucose for gold thiomalate. ${ }^{*}$ The pathogenesis of the syndrome is not known, although the similarity between the symptoms of rheumatoid arthritis and a postinjection reaction suggests that gold exacerbates an already existing disease. Indirect evidence supporting this view is derived from the immunological findings in the synovial fluid aspirated during a postinjection reaction; these are identical with those in active rheumatoid arthritis. ${ }^{910}$

The clearance of heat-damaged erythrocytes from the circulation provides a simple and reproducible way of determining the activity of the splenic component of the reticuloendothelial system, ${ }^{11}$ and we used this method to investigate the in-vivo effects of gold on the system. Our results show clearly that therapeutic doses of gold thiomalate delay the clearance of heatdamaged erythrocytes and that the clearance times are comparable to those in patients who have undergone splenectomy. ${ }^{12}$ We do not know how long this suppression lasts, but in the present patient damaged red cells were found in the circulation 18 hours after the injection of gold. We also do not know how gold delays the red-cell clearance, although available evidence suggests that it inhibits macrophage function rather than influencing splenic blood flow. Gold accumulates in phagocytic cells ${ }^{1314}$ and impairs the ability of these cells to ingest particulate material. Sequential studies on man using a modified skinwindow technique also showed a transient and reversible inhibition of macrophage phagocytic activity after the injection of gold. ${ }^{15}$ Several in-vitro studies showed that gold thiomalate is a powerful inhibitor of both antigen-triggered and mitogentriggered lymphocyte DNA synthesis, ${ }^{16-10}$ and careful analysis of this phenomenon showed that its inhibitory effects are directed against the monocytes present in the culture system. ${ }^{20}$

If gold also impairs the ability of the macrophage to remove immune complexes from the circulation then it would temporarily disturb the equilibrium between their formation, deposition, and removal and lead to an increased quantity of immune complexes deposited in the tissues. It is unlikely that the syno- vial membrane would provide a physical barrier to the intraarticular accumulation of circulating immune complexes, since large complexes of IgM rheumatoid factor, and IgG equilibrate rapidly between the blood and synovial fluid. ${ }^{21}$ Defective clearance of locally formed immune complexes might also contribute to the high concentrations found in the synovial fluid. Either or both of these mechanisms may have been responsible for the high concentration of immune complexes seen in this patient's synovial fluid and might have initiated a local inflammatory response by activating the complement system. That inhibition of reticuloendothelial function may be important in producing a postinjection reaction is supported by the observation that gold thioglucose, an oily suspension of gold, is much less potent in delaying the clearance of red cells. Although more information is clearly needed, it may nevertheless partly explain why this preparation abolishes or reduces the severity of the postinjection reaction induced by gold thiomalate. We can only speculate whether these differences are attributable to the higher serum gold values achieved after the injection of gold thiomalate or to differences in the biological activity of the thioglucose and thiomalate moieties.

Two factors therefore appear to be necessary before patients develop a postinjection reaction : inhibition of reticuloendothelial function by gold and the presence of circulating immune complexes. If the gold does not inhibit the reticuloendothelial system even when injected into patients with circulating immune complexes it will not produce any exacerbation of the patient's symptoms. Nevertheless, other factors, as yet unidentified, are clearly necessary for the expression of this syndrome, since the patient developed only two reactions even though immune complexes were present in the circulation for several months and he received weekly injections of gold. Factors regulating capillary permeability might be particularly important, since they would influence the tissue deposition of immune complexes. Capillary permeability is increased in rheumatoid arthritis, ${ }^{21}{ }^{23}$ and in experimental animals histamineinduced changes in permeability are important in allowing immune complexes to localise in the walls of blood vessels and in the tissues. ${ }^{24}$ The raised concentrations of $\mathrm{ClqB}$ but not $\mathrm{KgB}$ complexes during the time the patient was receiving antihistamines were indirect evidence that histamine-induced changes in vessel permeability may selectively change the distribution of immune complexes between the intravascular and extravascular spaces. Other actions of gold, however, such as its inhibitory effects on lysosomal enzymes or complement activation might also determine the number of postinjection reactions experienced by the patient.

Our observations may show another way in which the host is susceptible to an immune-complex disease and suggest that the mechanism includes a transient inhibition of the function of the reticuloendothelial system.

We thank Mr C Cotton for preparing the heat-damaged cells, and Dr G Hughes for helpful comments on the manuscript. Dr B D Williams is grateful for the financial support of the Wellcome Trust.

\section{References}

${ }^{1}$ Empire Rheumatism Council, Research Subcommittee, Annals of the Rheumatic Diseases, 1961, 20, 315.

2 Cooperative Clinics Committee of the ARA, Arthritis and Rheumatism, 1973, 16, 353.

3 Sigler, J W, Bluhm, G B, and Duncan, H, Annals of Internal Medicine, $1974,80,21$.

${ }^{4}$ Lachman, P J, and Hobart, M J, in Handbook of Experimental Immunology, ed D M Weir, p 5 Al. London, Blackwell Scientific Publications, 1978

${ }^{5}$ Perrin, L H, Lambert, P H, and Meischer, P A, fournal of Clinical Investigation, 1975, 56, 165.

${ }^{6}$ Pussell, B A, et al, Lancet, 1978, 2, 359.

7 Bowring, C S, Glass, H I, and Lewis, S M, fournal of Clinical Pathology, 1976, 29, 852.

${ }^{8}$ Halla, J T, Hardin, J G, and Linn, J E, Arthritis and Rheumatism, 1977, 6, 1188.

9 Zubler, R H, et al, fournal of Clinical Investigation, 1976, 57, 1308.

10 Ruddy, S, and Austen, K F, Arthritis and Rheumatism, 1970, 13, 713. 
11 Pettit, J E, Clinics in Haematology, 1977, 6, 639.

12 Crome, P, and Mollison, P L, British fournal of Haematology, 1964, 10 , 137.

13 Ghadially, F N, et al, fournal of Pathology, 1978, 124, 77.

14 Vernon-Roberts, B, et al, Annals of the Rheumatic Diseases, 1976, 35, 477.

15 Jessop, J D, Vernon-Roberts, B, and Harris, J, Annals of the Rheumatic Diseases, 1973, 32, 294.

${ }^{16}$ Cahill, R N P, Experientia, 1971, 27, 913.

17 Lies, R B, Cardin, C, and Paulus, H E, Annals of the Rheumatic Diseases, 1977, 36, 216.
18 Harth, M, et al, Clinical and Experimental Immunology, 1977, 27, 357.

19 Naot, Y, and Merchav, S, Infection and Immunity, 1978, 21, 340.

${ }^{20}$ Lipsky, P E, and Ziff, M, fournal of Clinical Investigation, 1977, 59, 455.

${ }^{21}$ Bluestone, R, et al, Annals of the Rheumatic Diseases, 1970, 29, 47.

22 Jayson, M I V, and Barks, J S, British Medical fournal, 1971, 1, 555.

${ }^{23}$ Marks, J, Burkett, D, and Shuster, S, British Medical fournal, 1972, 1, 782.

${ }^{24}$ Cochrane, C G, and Koffler, D, Advances in Immunology, 1973, 16, 185.

(Accepted 15 fune 1979)

\title{
Association between raw milk and human Salmonella dublin infection
}

\author{
S BENSON WERNER, GEORGE L HUMPHREY, ICHIRO KAMEI
}

British Medical fournal, 1979, 2, 238-241

\section{Summary and conclusions}

Between 1971 and 1975 the mean annual incidence of human Salmonella dublin infection in California increased more than five-fold. Investigation of the increase showed an association with exposure to raw milk in 44 out of 113 cases. Of these 44 patients, 35 had used certified raw milk from a single dairy. Faecal swabs confirmed $S$ dublin infection in the dairy herd and the milk, and so a pasteurisation order was issued. $S$ dublin appears to be an unusually invasive and lifethreatening salmonella serotype: $65 \%$ of isolations were obtained from non-faecal specimens (mainly blood cultures), 89 patients $(80 \%)$ were admitted to hospital and 22 patients died. Almost three-quarters of the patients were aged 20 or over, and half had serious underlying diseases, particularly leukaemias and lymphomas. Five patients presented with infected vascular lesions that included aneurysms with abscesses and infections of previous arterial graft sites.

The public's increasing desire for a "health food" such as raw milk should be tempered with an appreciation of its attendant risk to health.

\section{Introduction}

Salmonellosis is one of the most prevalent zoonotic diseases. More than 20000 cases in man are reported annually in the USA, ${ }^{1}$ but the true incidence is probably about 100 times greater." Four clinical types of salmonella infection occurnamely, gastroenteritis, enteric fever, focal abscess, and an asymptomatic carrier state. ${ }^{3}$ These are not mutually exclusive, and one person with the infection may rarely exhibit all four patterns in succession. Over 1700 salmonella serotypes have

Infectious Disease Section, California Department of Health Services, Berkeley, California, USA

S BENSON WERNER, MD, medical epidemiologist

GEORGE L HUMPHREY, DVM, veterinary epidemiologist

Acute Communicable Disease Control Division, Los Angeles County Department of Health Services, Los Angeles, California

ICHIRO KAMEI, MD, chief (present appointment: health officer, Central District, Los Angeles County Department of Health Services) been identified. ${ }^{1}$ Each is potentially capable of producing any of the four clinical patterns, but gastroenteritis is the most common. Some serotypes cause more invasive disease-for example, patients infected with Salmonella paratyphi and $S$ typhi commonly present with enteric fever, while patients with $S$ cholerae-suis commonly present with focal abscesses such as osteomyelitis as well as enteric fever. ${ }^{34}$

The pattern of infection characteristic of $S$ dublin in man has not been identified, partly because this serotype, which is host-adapted to cattle, has rarely been reported. Between 1963 and 1970 an average of only four cases of $S$ dublin per year were identified in California. When a sudden increase occurred in 1971 we undertook an investigation to identify possible sources of infection and to define the epidemiology of $S$ dublin infection. We here report the epidemiological features of patients infected with $S$ dublin, the invasiveness of this serotype, and the association of this disease with the use of raw milk during 1971-5.

\section{Materials and methods}

Under California State regulations all laboratories that isolate Salmonella spp are required to submit the isolates to the State Department of Health Services for serotype identification. These specimens are examined at the Microbial Diseases Laboratory according to standard methods. ${ }^{5}$ The salmonella surveillance programme, based on these laboratory reports and conducted by the infectious disease section, signalled the increased incidence of $S$ dublin infection in 1971.

Questionnaire survey-In 1971 we developed a comprehensive questionnaire to obtain clinical and epidemiological information from all patients in California known to be infected with $S$ dublin. The questions covered any history of contact with people, pets, or other animals ill with diarrhoea or salmonellosis; customary diet before the onset of the illness-for example, type of eggs (cracked, powdered, raw, etc), milk (powdered, raw, etc), other milk products, and many other foods previously implicated in salmonella infection; use of pharmaceutical preparations derived from animal sources (thyroid, pancreatic hormones, etc); previous admissions to hospital or outpatient investigation, especially of the gastrointestinal tract (where we were concerned about the use of carmine dye to study bowel transit time, ${ }^{6}$ sigmoidoscopy, ${ }^{7}$ or gastrointestinal endoscopy $\left.{ }^{8}\right)$; and travel before onset and participation in any sports entailing contact with water. The questionnaires were administered mainly during home visits and less commonly by telephone. If a patient died before he had been contacted the part of the questionnaire relating to diet was completed with the help of a family member, neighbour, or close friend.

Study of implicated dairy-A large proportion of patients reported using certified raw milk from one dairy (dairy $\mathrm{X}$ ). Thus a study was conducted to identify and remove any salmonella-infected cattle from the two herds totalling 3100 milking cows owned by this dairy. In November 1971 we requested that the county milk commission 